Jurnal Akuntansi dan Keuangan (JAK)

Volume 6, No. 2 Oktober Tahun 2021

Page: 27 - 36

http://ojs.uho.ac.id/index.php/jak-uho/issue/archive

e-ISSN: 2088-4656

\title{
ANALISIS KREDIT USAHA RAKYAT (KUR) BAGI PENGEMBANGAN UMKM DI KOTA KENDARI (Studi Kasus Pada Bank Sultra)
}

\section{Muntu Abdullah ${ }^{1}$, Sulvariany Tamburaka ${ }^{2}$, Isda $^{3}$ \\ Jurusan Akuntansi Fakultas Ekonomi dan Bisnis Universitas Halu Oleo Kendari Sulawesi Tenggara}

\begin{abstract}
ABSTRAK
Penelitian ini bertujuan untuk menganalisis Bagaimana Perkembangan Usaha Mikro, Kecil, Menengah (UMKM) dalam pengembangan sektor usaha sebelum dan sesudah adanya penggunaan dana Kredit Usaha Rakyat (KUR). Metode analisis yang digunakan dalam penelitian ini adalah metode analisis deskriptif kualitatif. Sumber data yang digunakan data primer dan data sekunder. Metode pengumpulan data yang digunakan dalam penelitian ini adalah wawancara dan dokumentasi. Hasil dari penelitian ini menunjukan bahwa setelah adanya dana Kredit Usaha Rakyat (KUR) yang diluncurkan pemerintah melalui Bank Sultra sangat berdampak positif dalam membantu pelaku UMKM dalam mengembangkan usahanya, baik dari segi permodalan, omset penjualan, dan dari segi keuntungan yang sangat berpengaruh dalam menumbuh kembangkan usaha UMKM. Perkembangan kinerja UMKM setelah adanya dana Kredit Usaha Rakyat (KUR) mengalami peningkatan di bandingkan sebelum adanya dana KUR di tahun-tahun sebelumnya, hal ini dapat dilihat dengan adanya perbedaan sebelum dan sesudah adanya dana Kredit Usaha Rakyat (KUR).
\end{abstract}

Kata kunci : UMKM, KUR, Bank Sultra.

\section{ABSTRACT}

This study aims to analyze how the development of Micro, Small and Medium Enterprises (MSMEs) in the development of the business sector before and after the use of People's Business Credit (KUR) funds. The analytical method used in this research is a qualitative descriptive analysis method. The data source used is primary data and secondary data. Data collection methods used in this study were interviews and documentation. The results of this study indicate that after the existence of the People's Business Credit (KUR) fund launched by the government through Bank Sultra has a very positive impact in helping MSMEs in developing their business, both in terms of capital, sales turnover, and in terms of profits which are very influential in growing and developing. UMKM businesses. The development of MSME performance after the existence of the People's Business Credit (KUR) fund has increased compared to before the KUR fund in previous years, this can be seen by the difference before and after the existence of the People's Business Credit (KUR) fund.

Keywords: MSMEs, KUR, Bank Sultra. 
Jurnal Akuntansi dan Keuangan (JAK)

Volume 6, No. 2 Oktober Tahun 2021

Page: 27 - 36

http://ojs.uho.ac.id/index.php/jak-uho/issue/archive

e-ISSN: 2088-4656

\section{LATAR BELAKANG}

Krisis yang menimpa Indonesia tahun 1997 diawali dengan krisis nilai tukar rupiah terhadap dollar AS dan krisis moneter yang berdampak pada perekonomian Indonesia yakni resesi ekonomi. Hal ini merupakan pelajaran yang sangat penting untuk kembali mencermati suatu pembangunan ekonomi yang benar-benar memiliki struktur yang kuat dan dapat bertahan dalam situasi apapun. Usaha mikro, kecil dan menengah telah menjadi isu yang menarik untuk dicermati dan disikapi. Menurut Wahyuni, dkk (2005:91) hal ini dikarenakan ada beberapa alasan antara lain : Saat krisis sektor UMKM dapat bertahan sampai saat ini,Perhatian pemerintah terhadap sektor UMKM masih kurang,Sektor UMKM yang jumlahnya cukup banyak sangat potensial dalam menyerap tenaga kerja,Sektor UMKM memiliki peran penting dan kontribusinya cukup besar dalam struktur perekonomian nasional.

Pengembangan UMKM masih dilanda berbagai hambatan dan tantangan dalam menghadapi dunia usaha yang semakin ketat. Namun demikian dengan berbagai keterbatasan yang ada, UMKM masih diharapkan mampu menjadi andalan perekonomian Indonesia. Usaha Mikro Kecil Menengah diharapkan dapat berperan sebagai salah satu sumber penting dalam meningkatan sumber pendapatan dan memperluas kesempatan kerja bagi masyarakat. Di Indonesia UMKM telah menjadi bagian penting dari sistem perekonomian. Hal ini dikarenakan UMKM merupakan unit-unit usaha yang lebih banyak jumlahnya dibandingkan usaha industri berskala besar dan memiliki keunggulan dalam menyerap tenaga kerja lebih banyak dan juga mampu mempercepat proses pemerataan sebagai bagian dari pembangunan.

Usaha mikro kecil dan menengah (UMKM) mempunyai peran yang cukup penting dalam membangun perekonomian di Indonesia. Terbukti di saat krisis ekonomi melanda Indonesia, pemerintah sangat mengandalkan peran UMKM untuk memperkecil dampak negatif dari krisis ekonomi. Ketika krisis ekonomi terjadi banyak sektor yang mengalami pertumbuhan pada output yang menurun. Setidaknya ada dua faktor yang memainkan peran sangat penting pada saat itu untuk mengurangi efek-efek negatif terhadap kemiskinan.

UMKM mempunyai peran penting dalam pembangunan ekonomi karena tingkat penyerapan tenaga kerjanya yang relatif tinggi dan kebutuhan modal investasinya yang kecil, UMKM bisa dengan fleksibel menyesuaikan dan menjawab kondisi pasar yang terus berubah. Hal ini membuat UMKM tidak rentan terhadap berbagai perubahan eksternal. UMKM justru mampu dengan cepat menangkap berbagai peluang, misalnya untuk melakukan produksi yang bersifat substitusi impor dan meningkatkan pemenuhan kebutuhan dalam negeri. Karena itu, pengembangan UMKM dapat menunjang diversifikasi ekonomi dan percepatan perubahan struktural, yang merupakan prasyarat bagi pembangunan ekonomi jangka panjang yang stabil dan berkesinambungan. Upaya penumbuhan kemampuan dan ketangguhan Usaha Mikro Kecil dan Menengah (UMKM) yang memiliki jumlah besar dan tersebar di seluruh tanah air, merupakan kegiatan yang tak dapat dipisahkan dari upaya menumbuhkan kemampuan, ketangguhan dan ketahanan nasional secara keseluruhan. 
Jurnal Akuntansi dan Keuangan (JAK)

Volume 6, No. 2 Oktober Tahun 2021

Page: 27 - 36

http://ojs.uho.ac.id/index.php/jak-uho/issue/archive

e-ISSN: 2088-4656

Tabel 1.1

Data Perkembangan Usaha Mikro, Kecil dan Menengah (UMKM) di Kota Kendari Tahun 2017-2019

\begin{tabular}{|c|c|c|c|c|c|c|}
\hline No & Indikator & 2015 & 2016 & 2017 & 2018 & 2019 \\
\hline 1 & $\begin{array}{c}\text { Pertanian, Kehutanan, dan } \\
\text { Perikanan }\end{array}$ & $11,00 \%$ & $11,32 \%$ & $11,54 \%$ & $12,11 \%$ & $12,33 \%$ \\
\hline 2 & Pedagang Besar dan Eceran & $16,1 \%$ & $16,32 \%$ & $16,62 \%$ & $16,44 \%$ & $16,47 \%$ \\
\hline 3 & Lainnya & $1,81 \%$ & $1,72 \%$ & $1,65 \%$ & $1,61 \%$ & $1,54 \%$ \\
\hline Total & & $28,91 \%$ & $29,36 \%$ & $29,81 \%$ & $30,16 \%$ & $30,34 \%$ \\
\hline
\end{tabular}

Sumber: kendarikota.bps.go.id

Berdasarkan tabel 1.1 data perkembangan UMKM dari tahun 2015-2019 mengalami fluktuasi dari tahun ke tahun hal ini di sebabkan oleh: dari indikator pertanian, kehutanan dan perikanan dikarenakan adanya fluktuasi yang di sebabkan adanya perubahan musim, hama, dan faktor-faktor lain yg dapat menghambat produksi yg dapat mempengaruhi pendapatan. Sementara pada indikator pedagang besar maupun kecil di pengaruhi oleh jumlah konsumen, ifen dan kegiatan-kegiatan hari besar maupun faktor lain. Jika jumlah konsumen meningkat maka pendapatan UMKM akan ikut meningkat begitu pun sebaliknya. Ifen sangat berperan dalam meningkatkan pendapatan UMKM karena jumlah konsumen cenderung ikut meningkat.

\section{Pengertian Bank}

\section{LANDASAN TEORI}

Ada beberapa macam pengertian bank menurut para ahli, diantaranya yaitu: Menurut Kasmir (2014:24) Bank adalah "Lembaga keuangan yang kegiatan utamanya menerima simpanan giro,tabungan dan deposito. Kemudian bank juga dikenal sebagai tempat untuk meminjam uang (kredit) bagi masyarakat yang membutuhkan". Menurut A. Abdurahman (2003) bank adalah "Suatu lembaga keuangan yang melaksanakan berbagai macam jasa, seperti memberikan pinjaman, mengedarkan mata uang, pengawasan terhadap mata uang, bertindak sebagai tempat penyimpanan benda-benda berharga, membiayai usaha-usaha perusahaan".

Pengertian Bank menurut Kamus Perbankan yang disusun oleh tim penyusun Kamus Perbankan Indonesia yaitu: "Bank adalah suatu badan usaha dibidang keuangan yang menarik uang dari dan menyalurkan kredit dan jasa-jasa dalam lalu lintas pembayaran dan peredaran uang".

\section{Tugas Dan Fungsi Bank Umum}

\section{Tugas Bank UMUM}

Adapun yang menjadi tugas utama bank adalah sebagai berikut :

1. Menetapkan dan melaksanakan kebijakan moneter :

a. Menetapkan sasaran monter dengan memperhatikan laju inflasi yang ditetapkannya.

b. Melakukan pengendalian moneter dengan menggunakan cara-cara termasuk tetapi tidak terbatas pada : 
Jurnal Akuntansi dan Keuangan (JAK)

Volume 6, No. 2 Oktober Tahun 2021

Page: 27 - 36

http://ojs.uho.ac.id/index.php/jak-uho/issue/archive

e-ISSN: 2088-4656

1) Operasi pasar terbuka di pasar uang, baik rupiah maupun valuta asing

2) Penetapan tingkat diskonto

3) Penetapan cadangan wajib minimum dan

4) Pengaturan kredit dan pembiayaan

2. Mengatur dan menjaga kelancaran sistem pembayaran

a) Melaksanakan dan memberikan persetujuan dan izin atas jasa sisa pembayaran

b) Mewajibkan penyelenggara jasa sistem pembayaran untuk menyampaikan laporan tentang kegiatannya

3. Menetapkan penggunaan alat pembayaran

a) Mengatur dan mengawasi bank

\section{Fungsi Bank Umum}

Penghimpun dana Untuk menjalankan fungsinya sebagai penghimpun dana maka

Bank memiliki beberapa sumber yang secara garis besar ada enam sumber, yaitu:

1. Dana yang bersumber dari bank sendiri yang berupa setoran modal waktu pendirian.

2. Dana yang berasal dari masyarakat luas yang dikumpulkan melalui usaha perbankan seperti usaha simpanan giro, deposito dan tabanas.

3. Dana yang bersumber dari Lembaga Keuangan yang diperoleh dari pinjaman dana yang berupa Kredit Likuiditas dan Call Money (dana yang sewaktu-waktu dapat ditarik oleh bank yang meminjam)

4. Penyalur/pemberi Kredit Bank dalam kegiatannya tidak hanya menyimpan dana yang diperoleh, akan tetapi untuk pemanfaatannya bank menyalurkan kembali dalam bentuk kredit kepada masyarakat. yang memerlukan dana segar untuk usaha. Tentunya dalam pelaksanaan fungsi ini diharapkan bank akan mendapatkan sumber pendapatan berupa bagi hasil atau dalam bentuk pengenaan bunga kredit. Pemberian kredit akan menimbulkan resiko, oleh sebab itu pemberiannya harus benar-benar teliti dan memenuhi persyaratan.

5. Penyalur dana-dana yang terkumpul oleh bank disalurkan kepada masyarakat dalam bentuk pemberian kredit, pembelian surat-surat berharga, penyertaan, pemilikan harta tetap.

Pelayan Jasa Bank dalam mengemban tugas sebagai "pelayan lalu-lintas pembayaran uang"melakukan berbagai aktivitas kegiatan antara lain pengiriman uang, inkaso, cek wisata, kartu kredit dan pelayanan lainnya.

\section{Pengertian Kredit}

Undang-Undang Republik Indonesia Nomor 10 Tahun 1998 Tentang Perubahan Atas Undang-Undang Nomor 7 Tahun 1992 Tentang Perbankan Kredit adalah penyediaan uang atau tagihan yang dapat dipersamakan dengan itu, berdasarkan persetujuan atau kesepakatan pinjam-meminjam antara Bank dengan pihak lain yang mewajibkan pihak peminjam untuk melunasi utangnya setelah jangka waktu tertentu dengan pemberian bunga;

Kredit yang diberikan oleh Bank dapat didefinisikan sebagai penyediaan uang atau tagihan yang dapat dipersamakan dengan itu, berdasarkan persetujuan atau kesepakatan 
Jurnal Akuntansi dan Keuangan (JAK)

Volume 6, No. 2 Oktober Tahun 2021

Page: 27 - 36

http://ojs.uho.ac.id/index.php/jak-uho/issue/archive

e-ISSN: 2088-4656

pinjam-meminjam antara Bank dengan pihak lain yang mewajibkan pihak peminjam untuk melunasi hutangnya setelah jangka waktu tertentu dengan jumlah bunga, imbalan atau pembagian hasil keuntungan (Taswan, 2003 : 163).

\section{Kredit Usaha Rakyat (KUR)}

Kredit Usaha Rakyat, yang selanjutnya disingkat KUR, adalah kredit/ pembiayaan kepada Usaha Mikro Kecil Menengah (UMKM) dalam bentuk pemberian modal kerja dan investasi yang didukung fasilitas penjaminan untuk usaha produktif. KUR adalah program yang dicanangkan oleh pemerintah namun sumber dananya berasal sepenuhnya dari dana bank.

\section{Usaha Mikro,Kecil dan Menengah (UMKM) Usaha Mikro}

Kriteria kelompok Usaha Mikro adalah usaha produktif milik orang perorangan dan/atau badan usaha perorangan yang memenuhi kriteria Usaha Mikro sebagaimana diatur dalam Undang-Undang ini. Menurut Keputusan Menteri Keuangan No. 40/KMK.06/2003 tanggal 29 Januari 2003 UMKM yaitu usaha mikro yaitu usaha produktif milik keluarga atau perorangan WNI dan memiliki hasil penjualan paling banyak Rp. 100.000 .000 (seratus juta rupiah) per tahun. Usaha mikro dapat mengajukan kredit kepada bank paling banyak Rp 50.000.000.

\section{Usaha Kecil}

Kriteria Usaha Kecil Adalah usaha ekonomi produktif yang berdiri sendiri, yang dilakukan oleh orang perorangan atau badan usaha yang bukan merupakan anak perusahaan atau bukan cabang perusahaan yang dimiliki, dikuasai, atau menjadi bagian baik langsung maupun tidak langsung dari usaha menengah atau usaha besar yang memenuhi kriteria Usaha Kecil sebagaimana dimaksud dalam Undang-Undang ini. Menurut Undang-Undang No. 9 Tahun 1995, usaha kecil adalah usaha produktif yang berskala kecil dan memilki kekayaan bersih paling banyak Rp. 200.000.000, tidak termasuk tanah dan bangunan tempat usaha atau memiliki hasil penjualan paling banyak Rp. 1.000.000.000 pertahun serta dapat menerima kredit dari Bank diatas Rp. 50.000.000 sampai Rp 500.000.000 Juta.

\section{Usaha Menengah}

Kriteria Usaha Menengah Adalah usaha ekonomi produktif yang berdiri sendiri, yang dilakukan oleh orang perseorangan atau badan usaha yang bukan merupakan anak perusahaan atau cabang perusahaan yang dimiliki, dikuasai, atau menjadi bagian baik langsung maupun tidak langsung dengan usaha kecil atau usaha besar dengan jumlah kekayaan bersih atau hasil penjualan tahunan sebagaimana diatur dalam UndangUndang ini.

Menurut Instruksi Presiden Republik Indonesia Nomor 10 Tahun 1999, usaha menengah adalah Usaha bersifat produktif yang memenuhi kriteria kekayaan bersih lebih besar dari Rp 200.000.000 (dua ratus juta rupiah) sampai dengan paling banyak sebesar Rp 10.000.000.000 (sepuluh milyar rupiah) tidak termasuk tanah dan bangunan tempat usaha. 
Jurnal Akuntansi dan Keuangan (JAK)

Volume 6, No. 2 Oktober Tahun 2021

Page: 27 - 36

http://ojs.uho.ac.id/index.php/jak-uho/issue/archive

e-ISSN: 2088-4656

\section{METODE PENELITIAN}

Objek penelitian ini adalah Analisis Kredit Usaha Rakyat (KUR) bagi pengembangan UMKM di Kota Kendari pada Bank Sultra, Jln. Mayjend Sutoyo No.95, Watu-Watu, Kendari.

Jenis data yang digunakan dalam penelitian adalah: Data kuantitatif adalah data berupa angka atau bilangan absolut yang dapat dikumpulkan dan dibaca relatif lebih mudah (Sunyoto, 2016:21). Dalam penelitian ini data kuantitatif diperoleh dari Bank Sultra yang relevan dengan judul skripsi, berupa angka-angka hasil pengisihan kuesioner yang dinyatakan dalam berbagai satuan. Data kualitatif adalah data berupa variasi-variasi presepsi yang berasal dari responden (Sunyoto, 2016:21). Dalam penelitian ini data kualitatif adalah datadata yang bersifat informatif yang diperoleh dalam bentuk pernyataan dari pihak Bank Sultra dan dari sumber lain yang relevan. Sumber data yang digunakan dalam peneltian ini berasal dari dua sumber, yaitu sebagai berikut Data primer Data primer adalah data asli yang dikumpulkan sendiri oleh peneliti untuk menjawab masalah penelitiannya secara khusus (Sunyoto, 2016: 21). Dalam penelitian ini bersumber langsung dari responden yang berhubungan dengan objek penelitian, yaitu Bank Sultra. Data dalam penelitian ini bersumber langsung dari wawancara dari pihak Bank Sultra dan nasabah Kredit Usaha Rakyat (KUR). Data sekunder, yaitu data yang bersumber dari catatan yang ada pada perusahaan dan dari sumber lainnya dengan mengandalkan studi kepustakaan yang ada hubungannya dengan objek penelitian (Sunyoto, 2016: 21).

Teknik analisis data yang digunakan untuk penelitian ini adalah metode analisis deskriptif kualitatif adalah menganalisis, menggambarkan, dan meringkas sebagai kondisi,situasi dan berbagai data yang dikumpulkan berupa hasil wawancara atau pengamatan mengenai masalah yang di teliti yang terjadi di lapangan (I Made Whinarta 2016:155).

Metode penelitian ini sering digunakan untuk meneliti pada kondisi objek yang alamiah yakni objek yang berkembang apa adanya, tidak dimanipulasi oleh peneliti, kehadiran peneliti tidak mempengaruhi dinamika pada objek tersebut dimana peneliti adalah instrumen kunci.

\section{HASIL DAN PEMBAHASAN}

\section{Analisis Perkembangan UMKM Setelah Adanya Penerima Dana KUR}

Berikut ini adalah perbedaan UMKM sebelum dan sesudah menggunaan dana KUR dari Bank Sultra, antara lain :

\section{Modal}

Untuk mendirikan atau menjalankan suatu usaha diperlukan sejumlah modal dan tenaga. Modal dalam bentuk uang diperlukan untuk membiayai segala keperluan usaha. 
Jurnal Akuntansi dan Keuangan (JAK)

Volume 6, No. 2 Oktober Tahun 2021

Page: 27 - 36

http://ojs.uho.ac.id/index.php/jak-uho/issue/archive

e-ISSN: 2088-4656

Seperti yang diungkapkan oleh informan berikut, mereka mengatakan mengatakan sangat membutuhkan tambahan modal ketika mendapat pesanan konveksi yang sangat banyak. Maka mereka mengambil tambahan modal dari pinjaman KUR di Bank Sultra :

Tabel 4.1

Data Informan Nasabah KUR Bank Sultra Dari Segi Permodalan

\begin{tabular}{|l|l|l|l|l|}
\hline \multirow{2}{*}{ No } & \multirow{2}{*}{ Nama } & \multicolumn{3}{|c|}{ Modal UMKM / Tahun } \\
\cline { 3 - 5 } & & $\begin{array}{c}\text { Sebelum KUR } \\
(\mathbf{R p})\end{array}$ & $\begin{array}{c}\text { Pinjaman KUR } \\
(\mathbf{R p})\end{array}$ & $\begin{array}{c}\text { Modal Akhir } \\
(\mathbf{R p})\end{array}$ \\
\hline 1 & Asri & 40.000 .000 & 25.000 .000 & 65.000 .000 \\
\hline 2 & Ahmad Syaroni & 25.000 .000 & 25.000 .000 & 50.000 .000 \\
\hline 3 & Sitti Wahyuni & 10.000 .000 & 20.000 .000 & 30.000 .000 \\
\hline 4 & Mustar & 7.000 .000 & 20.000 .000 & 27.000 .000 \\
\hline 5 & Kusnadi & 5.000 .000 & 15.000 .000 & 20.000 .000 \\
\hline
\end{tabular}

Sumber: data diolah Tahun 2021

Tabel 4.1 diatas menunjukkan bahwa seluruh modal UMKM nasabah KUR meningkat setelah mendapatkan dana KUR. Hal ini menunjukan bahwa dana KUR berpengaruh secara positif terhadap perkembangan modal UMKM dilihat dari modal awal yang ditambah dengan jumlah pinjaman dana KUR dan perkembangan modal setelah mendapat dana KUR selalu mengalami kenaikan.

\section{Omzet Penjualan}

Omzet penjualan adalah akumulasi dari kegiatan penjualan suatu produk barang dan jasa yang dihitung secara keseluruhan selama kurun waktu tertentu secara terus menerus atau dalam satu proses akuntansi. Berikut perbedaan Omset penjualan sebelum dan sesudah adanya dana KUR yang di ungkapkan ke lima informan kunci :

Tabel 4.2

Data Omzet Penjualan Nasabah KUR

\begin{tabular}{|l|l|l|l|}
\hline \multirow{2}{*}{ No } & \multirow{2}{*}{ Nama } & \multicolumn{2}{|c|}{ Omzet Penjualan / Bulan } \\
\cline { 3 - 4 } & & $\begin{array}{c}\text { Sebelum KUR } \\
(\mathbf{R p})\end{array}$ & $\begin{array}{c}\text { Setelah KUR } \\
(\mathbf{R p})\end{array}$ \\
\hline 1 & Asri & 15.000 .000 & 23.000 .000 \\
\hline 2 & Ahmad Syaroni & 30.000 .000 & 55.000 .000 \\
\hline 3 & Sitti Wahyuni & 16.000 .000 & 21.500 .000 \\
\hline 4 & Mustar & 18.000 .000 & 25.000 .000 \\
\hline 5 & Kusnadi & 7.500 .000 & 10.000 .000 \\
\hline
\end{tabular}

Sumber: data diolah Tahun 2021

Dari data omzet penjualan pada tabel 4.2 diatas menunjukkan bahwa omzet penjualan mengalami kenaikan secara signifikan setelah mendapatkan KUR di Bank Sultra. Hal ini menunjukkan terdapat perbedaan yang signifikan terhadap omzet penjualan pada UMKM 
Jurnal Akuntansi dan Keuangan (JAK)

Volume 6, No. 2 Oktober Tahun 2021

Page: 27 - 36

http://ojs.uho.ac.id/index.php/jak-uho/issue/archive

e-ISSN: 2088-4656

sebelum dan setelah menggunakan KUR. Faktor modal yang bertambah setelah mendapat KUR sangat berpengaruh pada omzet penjualan yang juga ikut bertambah.

\section{Keuntungan}

Keuntungan merupakan kegiatan pedagang yang mengurangkan beberapa biaya yang dikeluarkan dengan hasil penjualan yang diperoleh. Berikut keuntungan nasabah KUR sebelum dan sesudah adanya pinjaman dana KUR dari Bank Sultra :

Tabel 4.3

Tingkat Keuntungan Nasabah Umkm

\begin{tabular}{|l|l|l|l|}
\hline \multirow{2}{*}{ No } & \multirow{2}{*}{ Nama } & \multicolumn{2}{c|}{ Keuntungan / Bulan } \\
\cline { 3 - 4 } & & Sebelum KUR & Sesudah KUR \\
\hline 1 & Asri & 10.000 .000 & 16.000 .000 \\
\hline 2 & Ahmad Syaroni & 6.000 .000 & 9.000 .000 \\
\hline 3 & Sitti Wahyuni & 3.000 .000 & 5.000 .000 \\
\hline 4 & Mustar & 2.000 .000 & 4.500 .000 \\
\hline 5 & Kusnadi & 1.500 .000 & 3.000 .000 \\
\hline
\end{tabular}

Sumber: data diolah Tahun 2021

Dari data pada Tabel 4.3 keuntungan UMKM pada tabel diatas menunjukan bahwa keuntungan penjualan mengalami kenaikan secara signifikan setelah mendapatkan KUR. Hal ini menunjukkan terdapat perbedaan yang signifikan terhadap keuntungan penjualan pada UMKM sebelum dan setelah menggunakan KUR. Hal ini dipengaruhi oleh faktor modal yang bertambah setelah mendapat dana KUR maka omzet penjualan juga ikut bertambah. Seperti yang diketahui bahwa keuntungan adalah sejumlah uang yang diperoleh setelah semua biaya variabel termasuk biaya tetap operasional tertutupi.

Tabel 4.4

\section{Jumlah Nasabah Kur Di Bank SULTRA}

\begin{tabular}{|l|c|c|}
\hline No & Tahun & Jumlah \\
\hline 1 & 2018 & 195 orang \\
\hline 2 & 2019 & 945 orang \\
\hline 3 & 2020 & 1127 orang \\
\hline
\end{tabular}

Sumber: data diolah Tahun 2021

Tabel 4.4 menunjukan bahwa pada tahun 2018 jumlah nasabah Kur di Bank Sultra berjumlah 195 nasabah dan pada tahun 2019 menjadi 945 nasabah dan juga pada tahun 2020 naik menjadi 1127 nasabah, jumlah nasabah yang setiap tahun nya naik menunjukan bahwa KUR sangat berpengaruh positif dalam pengembangan UMKM di kota kendari. Sehingga tujuan pemerintah dalam hal ini membantu para pelaku UMKM dengan menyalurkan dana KUR untuk meningkatkan dan memperluas akses pembiyaan serta pengembangan kewirausahaan kepada pelaku UMKM sudah sangat efektif. 
Jurnal Akuntansi dan Keuangan (JAK)

Volume 6, No. 2 Oktober Tahun 2021

Page: 27 - 36

http://ojs.uho.ac.id/index.php/jak-uho/issue/archive

e-ISSN: 2088-4656

\section{KESIMPULAN, KETERBATASAN DAN REKOMENDASI}

\section{Kesimpulan}

Berdasarkan uraian pembahasan dan analisis dari hasil penelitian, maka dapat diambil kesimpulan sebagai berikut:

1. Perkembangan UMKM penerima dana KUR

Dalam hasil analisis perkembangan UMKM sebelum dan sesudah menerima KUR, mengenai modal, omzet penjualan,tingkat keuntungan. Maka dapat disimpulkan bahwa:

a. Kinerja UMKM yang dilihat dari modal menunjukkan perbedaan yang signifikan setelah menerima KUR. KUR yang diberikan oleh Bank Sultra memberikan dampak yang signifikan terhadap peningkatan kinerja pada UMKM. Hal ini dapat dilihat dari perbedaan modal sebelum dan setelah menerima dana KUR.

b. Kinerja UMKM yang dilihat dari omzet penjualan juga menunjukkan perbedaan yang signifikan setelah menerima KUR. KUR yang diberikan oleh Bank Sultra memberikan dampak yang signifikan terhadap peningkatan kinerja pada UMKM. Hal ini dapat dilihat dari perbedaan omzet penjualan sebelum dan setelah menerima KUR.

c. Kinerja UMKM yang dilihat dari keuntungan menunjukkan perbedaan yang signifikan setelah menerima KUR. KUR yang diberikan oleh Bank Sultra memberikan dampak yang signifikan terhadap peningkatan kinerja pada UMKM. Hal ini dapat dilihat dari perbedaan keuntungan sebelum dan setelah menerima KUR.

\section{Keterbatasan}

Penelitian ini memiliki keterbatasan sebagai berikut: Penelitian ini menggunakan metode analisis yaitu analisis deskriptif kualitatif yaitu menganalisis, menggambarkan, dan meringkas sebagai kondisi, situasi dan berbagai data yang di kumpulkan berupa wawancara atau pengamatan mengenai masalah yang di teliti yang terjadi di lapangan.

\section{Rekomendasi}

Saran yang diajukan oleh peneliti berdasarkan kesimpulan dan hasil penelitian adalah sebagai berikut:

1. Kepada pihak Bank Sultra selaku penyalur program pemerintah dibidang permodalan UMKM, disamping menawarkan produk pinjaman modal agar juga melakukan penyuluhan dan pengarahan kepada para pengusaha UMKM. Sehingga wujud tanggung jawab pemerintah untuk mensejahterakan rakyat dapat terlaksana.

2. Kepada para pengusaha UMKM, bahwa dalam penggunaan Kredit Usaha untuk tidak mencampur adukkannya dengan kebutuhan konsumsi agar pemanfaatannya lebih bijak dan lebih efisien sehingga hasil pun akan terlihat maksimal. 
Jurnal Akuntansi dan Keuangan (JAK)

Volume 6, No. 2 Oktober Tahun 2021

Page: 27 - 36

http://ojs.uho.ac.id/index.php/jak-uho/issue/archive

e-ISSN: 2088-4656

3. Diperlukan peran dari Dinas Ketenagakerjaan dalam meningkatkan kualitas tenaga kerja dengan melakukan program seperti pelatihan kepada masyarakat. Pelatihan ini akan berdampak pada penambahan skill terutama pada masyarakat yang putus sekolah. Sehingga dengan pelatihan ini akan dihasilkan tenaga kerja yang mandiri dan kreatif dalam berwirausaha.

4. Diperlukan peran dari Dinas Perindustrian Perdagangan dan Koperasi dalam mempromosikan produk UMKM di Kota kendari. Promosi ini akan berdampak terhadap peningkatan penjualan UMKM, sehingga akan meningkatkan pendapatan usaha.

\section{Daftar Pustaka}

Abdurahman A. 2003. Ensiklopedia Ekonomi Keuangan Perdagangan. Pradnya Paramita,Jakarta.

Badan Pusat Statistik Kota Kendari. 2020. Data Perkembangan Usaha Mikro, Kecil dan Menengah (UMKM) di Kota Kendari Tahun 2017-2019. kendarikota.bps.go.id. (20 Juni 2020)

Bank sultra.co.id. Kredit Usaha Rakyat, Bank Sultra Kredit Usaha Rakyat (diakses 04 oktober 2020).http://banksultra.co.id/v4/produk_dan_layanan/pinjaman/kur.html

Bank sultra.co.id. Kredit Multiguna, Manfaat dan persyaratan kredit multiguna, (diakses pada 05 oktober

2020).Http://Banksultra.Co.Id/V4/Produk_Dan_Layanan/Pinjaman/Multiguna.Ht $\underline{\mathrm{ml}}$

Dinas Perdagangan Kota Kendari. 2020. Tingkat Pertumbuhan Sektor UMKM Di Kota Kendari. http://sultraprov.go.id/berita terkini. (20 Juni 2020).

Kasmir. 2014. Bank Dan Lembaga Keuangan Lainnya.Yogyakarta: PT Rajagrafindo Persada

Republik Indonesia, Undang-Undang Nomor 10 Tahun 1998 Tentang Perubahan Atas Undang-Undang Nomor 7 Tahun 1992 Tentang Perbankan.

Sugiyono. 2004. Metode Penelitian. Bandung: Alfabeta.

Danang Sunyoto. 2016. Metodelogi Penelitian Akuntansi. Bandung: PT. Refika Aditama

Taswan. 2003. Akuntansi Perbankan: transaksi dalam valuta asing. Yogyakarta: UPP STIM YKPN. 